Swedish Institute for Social Research (SOFI)

Stockholm University

WORKING PAPER 1/2014

RESCALING INEQUALITY?

WELFARE REFORM AND LOCAL VARIATION IN SOCIAL ASSISTANCE PAYMENTS

by

Renate Minas, Olof Bäckman, Vibeke Jakobsen,

Tomas Korpi, Thomas Lorentzen, Timo Kauppinen 


\title{
Rescaling inequality? \\ Welfare reform and local variation in social assistance payments*
}

\author{
Renate Minas, \\ Department of Social Work, \\ Stockholm University \\ Tomas Korpi, \\ Swedish Institute \\ for Social Research, \\ Stockholm University
}

\author{
Olof Bäckman, \\ Swedish Institute \\ for Social Research, \\ Stockholm University
}

\author{
Thomas Lorentzen, \\ Department of Sociology, \\ University of Bergen
}

\author{
Vibeke Jakobsen, \\ Danish National Institute \\ for Social Research
}

Timo Kauppinen, Finnish National Institute for Health and Welfare

\begin{abstract}
Social assistance and other means tested benefits are the last resort in national social protection systems and variation in benefit receipt are in part a direct consequence of differences in means and needs. Variation may however also be related to local discretion over implementation of national legislation, implying inequality unintended by legislators. Such discretion is generally believed to have increased following decentralizing reforms in the 1990s, an international trend frequently referred to as devolution. More recent reforms have instead often implied recentralization and/or involved institutional cooperation of welfare agencies located at different vertical levels. Little is however known regarding the extent to which shifting divisions of power influences benefit receipt. Using individual level register data, multi-level modelling and a difference-in-difference approach we attempt to link changes in legislation to changes in inter-municipal differences in social assistance payments in the Nordic countries during the period 1990 to 2010 . Somewhat simplified, the assumption is that the more detailed the regulation the less variation is possible and vice versa. The results show the changes in inequality in the wake of the reforms to be heterogeneous, both in accordance with and contradictory to the starting hypothesis. Although some of the unexpected results are difficult to account for, others may be explained by the character or implementation of the reforms.

* We would like to acknowledge funding from the Nordic Council of Ministers, and Bäckman, Korpi and Minas also acknowledge funding from Riksbankens Jubileumsfond. In addition, Korpi received funding from the Swedish Council for Working Life and Social Research. Any errors are our own.
\end{abstract}




\section{Welfare reform and benefit inequality}

Social assistance schemes generally make up the last resort in countries' social protection systems, guaranteeing citizens help when they cannot support themselves and have exhausted other alternatives. The benefit's means tested character implies that variation in social assistance payments is foreseen by law, a normal and intended result of applicants' different needs and circumstances. Variation in assessments and payments can however also be generated by local government discretion in implementing national legislation, discretion providing them with varying degrees of leeway when adapting legislation to local conditions and formulating own policies. Thus, depending on where they live persons with the same circumstances and needs may face different eligibility criteria and/or receive different benefit amounts.

Local discretion is generally believed to have increased following decentralizing reforms in the 1990s, reforms which have been summarized under the heading devolution. In an effort to reduce unemployment, local governments were in many countries given increased responsibility for activation programs of various kinds and benefit payments have increasingly been linked to program participation. Some recent reforms have however implied recentralization, or involved institutional cooperation of welfare agencies located at different vertical levels. Yet, little is known regarding the impact of changes in vertical divisions of power on inequality

The distribution of responsibility between central and local government has also been an issue in the Nordic countries. Although the Nordic countries often are classified as a distinct type of welfare state (e.g. encompassing or social democratic), this tends to overlook the substantial differences within the cluster. Social assistance is a case in point. While the Nordic countries all have a nationally legislated single, general, means tested social assistance scheme there are notable differences in the extent and character of local discretion, and the countries have also seen a variety of reforms in the area of standardisation and institutional integration. 
The aim of this paper is to examine the relationship between shifting divisions of power and the degree of variation of social assistance payments in Denmark, Finland, Norway, and Sweden. Specifically, the reforms we examine relate to changes in local autonomy such as e.g. limiting or extending local responsibility regarding activation policies, processes of standardisation, and institutional integration of social assistance systems with labour market policy. Somewhat simplified, the assumption is that the more detailed the regulation the less variation is possible and vice versa.

We use individual level national register data that in Finland and Norway pertain to the whole population and in Denmark and Sweden to very large samples thereof. The data spans roughly the period 1990 to 2010. To examine the impact of the reforms for variation in social assistance payments we employ multi-level modelling controlling for both individual and municipal characteristics. In the subsequent Section 2 we review the literature on power shifts and inequality, before we in Section 3 briefly discuss the Nordic reforms. Section 4 contains a presentation of the data and the method used in the analysis. The results are presented in Section 5, which is followed by conclusions in Section 6.

\section{Reform trends and local variation}

In recent decades, reforms in developed welfare states have addressed the institutional structure of income protection and activation services. Throughout Europe, sub-national levels of government have become responsible for delivery of services as well as for regulation and financing tasks (Pollitt 2005; van Berkel et al. 2011; Minas and Øverby 2010; Minas et al. 2012). However, there were also reforms in the opposite direction, limiting local autonomy and transferring power back to the national level (Minas et al. 2012). To this may be added reforms addressing responsibilities at a particular level, e.g. through integration of separate benefit systems. Such institutional reforms were also central components of reforms to social assistance systems in both Canada and the USA.

This increased autonomy at sub-national levels with regard to social assistance has been part of a general debate around the advantages and disadvantages of locating different types of activities and responsibilities at different levels of government. The increase in 
local autonomy has been justified by beliefs that local governments are more able to design programs appropriate to local circumstances (De Vrijes 2000; Mosley 2003, 2009) and that central governments are better at setting directions for policy than they are at actually delivering the policies ('steering not rowing', Osborne and Gaebler 1992). One potential advantage of decentralized government is its ability to match policies to the heterogeneous preferences of individuals living in different territories, thus enhancing the distributive efficiency of government (Oates 1972).

Yet, differences in institutional capacities and socio-economic conditions within a country may counteract the potential benefits associated with the improved matching of policies to local needs and the greater territorial competition associated with decentralization (Rodrigues-Pose and Gill 2005). In countries with high levels of income inequality and/or large regional economic and political disparities, increased decentralization may in other words exacerbate rather than mitigate inequities.

A further argument for spatially regressive effects of decentralization is the weakening of the equalizing role of central government (Prud'homme 1995). National government may be understood as the ultimate guarantor of universalism in welfare delivery and responsible for upholding an equal standard of welfare (Bergmark and Minas 2007). Variations in welfare related to residence are from this perspective an equality problem and inconsistent with the idea of social citizenship (Marshall 1981, Johansson 2001). There is a fear that decentralization may result in geographically uneven distribution of resources - and therefore of benefits (Martínez-Vázquez and McNab 2003). Directly relevant to social assistance is the idea of migration "externality" (Hölsch and Kraus 2004), or that local decision making can result in migration of benefit recipients to municipalities providing relatively generous benefits (making them so-called "welfare magnets"). This results in an overburden of the generous municipalities' resources (and a relief to the stingier ones) eventually forcing generous municipalities to reduce benefit levels as well. 
Empirical research does not seem to have been able to adjudicate between these alternative visions, and a notable lack of consensus exists within the academic literature regarding the links between devolution and the distribution of wealth. However, this may in part be due to differences regarding the operationalisation and measurement of fiscal, financial and political decentralisation as well as the different inequality concepts used. Regarding the former, a useful distinction between different approaches is the one used in comparative welfare state research between analyses of social expenditures, social rights, and social transfer recipiency (van Oorschoot no date). These three types of data can then in turn be used either as the dependent or as an independent variable, were analyses using some measurement of welfare states as the dependent variable focus on the causes of welfare state development while analyses using the same measure as an independent variable focus on the consequences.

The three types of data have different strength and weaknesses. Expenditure data are for example readily available, yet may provide only a weak indication of e.g. country differences as they may primarily be driven by factors such as demographic change and business cycles. Rights data (i.e. data on legislation) is more difficult to come by and may only be available for certain types of cases. While suitable for the analysis of driving forces they may be problematic for the analyses of consequences as they may be unable to capture what citizens actually receive. This is on the other hand the strength of recipiency data, yet these are often unavailable. Ideally, an analysis of the inequality consequences of devolution would seem to be one using recipiency data as the dependent and rights data as an independent variable, yet this seems to be a rare combination.

Instead the use of expenditure data to measure decentralization has been common (e.g. regional share of total government expenditure). As noted above this has been heavily criticised in the comparative welfare state literature. Esping-Andersen for instance derides expenditures as "epiphenomenal to the theoretical substance of the welfare state" $(1990,19)$. This approach has also been the target of scathing critique in the literature focusing on devolution. Opponents stress that these indicators fail to identify the degree of expenditure autonomy of sub-national governments, to differentiate between tax and 
non-tax revenue sources, and fail to capture the proportion of intergovernmental transfers that are discretionary or conditional (Rodden 2004).

More promising is instead the approach used by Hooghe et al. (2008). They focus on legislation regulating the relationship between central and local government, for instance regional autonomy with regard to welfare policy, taxation and elections. This data was used by Tselios et al. (2012) as a measure of political decentralisation in an analysis of decentralisation and income inequality in Western Europe. The outcome variable was here based on individual income data, in many ways an ideal design. However, political decentralisation seemed to have a weak connection to inequality, something which may be related to the rather general nature of the indicators used. In addition, measures concerning political decentralization are often insensitive to variation within federal states or among non-federal countries and often fail to capture changes over time (Marks et al. 2008).

The question of generality is problematic in analyses of developments within a specific policy field, as the level and development of decentralisation may differ between policy areas. There is for instance reason to believe that there are stark differences in the legislation even in such closely related policy areas of social insurance and social assistance. Of greatest relevance for our analysis would therefore be studies focusing on social assistance legislation. One such comparative study is the one by Hölsch and Kraus (2004). Examining the relationship between the degree of decentralisation and poverty reduction through social assistance in five countries, they found that social assistance schemes with a medium degree of decentralization (France, Germany and Finland) are more effective in alleviating poverty than either extremely centralised (UK) or extremely decentralised systems (Italy). A somewhat similar approach was used by Van Mechelen and de Maesschalck (2009) who investigated the relationship between several dimensions of decentralisation (administration, decision-making and funding) at two levels of government (the sub-state and the local level) and generosity of social assistance benefits in 21 OECD countries. Generosity, or social adequacy, was measured in terms of net disposable income of general social assistance claimants as a percentage of the poverty 
line. The results indicate that social assistance benefits are more adequate in countries where the decision-making, funding and administration of social assistance schemes is controlled by the central government and in countries where central or sub-state governments set the basic social assistance rates and housing benefits while sharing funding liabilities with the local government level. Although the results from the two studies differ somewhat, they agree on the poor performance of decentralized systems.

These cross-sectional comparative analyses of poverty reduction are complemented by analyses of the impact of decentralization on welfare benefits in North America. Analyses of caseloads from both the USA and Canada indicate that reforms carried out in the 1990s increasing state autonomy with regard to policies vis-a-vis social assistance recipients contributed to a reduction in the number of benefit recipients (Blank 2002, Kneebone and White 2009). The precise reason for this seems unclear, yet one potential explanation may be the reduced benefit generosity as well as to lower take-up associated with US devolution (Mayers et al. 2002, Mayers and Gornick 2005).

Although interesting, these studies focus primarily on the level of the benefit, and not on variation among benefit recipients. Evidence on the link between decentralization and inequality is however provided in the previously mentioned studies by Mayers and Gornick (Mayers et al. 2002, Mayers and Gornick 2005) as they also examined changes in benefit inequality following welfare reform. While they found a somewhat mixed pattern, their overall conclusion was that inter-state variation in means tested cash and inkind benefit rates as well as in take-up had increased following the devolutionary reforms. The relationship between local autonomy and benefit variation was also examined in two Nordic studies, although these focused on centralization rather than decentralization. Bergmark (2001) studied inter-municipal variation in social assistance expenditures in Sweden following the introduction of a national benefit standard in 1998. This appeared to have had no impact on variations in expenditure, as the variation in benefit expenditures increased continuously throughout the 1990s. 
These studies used the coefficient of variation in municipal expenditures as their outcome measure. In their analysis of the introduction of governmental guidelines for social assistance benefits in Norway in 2001 (similar to the Swedish standard but formulated more loosely), Brandtzæg et al. (2006) instead examined the deviation of local benefit amounts from the national guidelines as well as the deviation of local benefit expenditures from the national average. In contrast to the other studies, they were also able to control for a number of structural differences between municipalities such as differences in population structure (and in some models also introduced municipal fixed effects). Their results showed a slight decrease in the average difference between local benefit amounts and the guideline rate after the introduction of guidelines, and this relatively weak effect was attenuated further when they turned to expenditures where no clear impact of the reform was found. This difference between the impact on set amounts and actual payments was seen as related to the discretion retained by caseworkers and administrators in the assessment of benefit needs. ${ }^{1}$

In sum, although the pattern was somewhat mixed, the US analyses tended to show a reduction in expenditure variation following the devolutionary reforms in the 1990s. In contrast, the Nordic studies examining centralizing reforms around the turn of the millennium only found a weak or no reduction of variation. One interpretation of these mixed results is that there may be differences in the legislation not captured in the analyses generating the differences in the results. Reforms do not always fall along a decentralisation-centralisation continuum but can involve a concomitant expansion and limitation of local autonomy (decentralised centralisation). In addition, different reforms with contradictory implications for local autonomy can be carried out simultaneously. Other differences between the studies may of course also be important, only the Norwegian study did for instance control for structural differences across localities. There is in other words a need for analyses that pay close attention to the particulars of the

\footnotetext{
1 The literature on variations in social assistance payments also encompass studies using so-called vignettes, i.e. hypothetical cases assessed by individual case workers. These studies unanimously show large variation in the assessments made by social workers, even within single social welfare offices (for Nordic examples see Terum 2003, Stranz 2007). Nonetheless, they are of less relevance here as they rarely focus on organizational dimensions.
} 
reforms while examining their impact using longitudinal data from representative samples controlling for confounding factors.

\section{De- and recentralisation of social assistance policies in Nordic countries}

All Nordic countries have means tested social assistance schemes were the right to support is stated in national legislation outlining the legislators' general intentions while at the same time giving local government varying degrees of implementation autonomy. When discussing the reforms in the four countries it is essential to take the starting point into consideration as decentralised systems seeing further decentralisation may be less likely to see an increased variation than centralised systems undergoing the same change. Comparing the countries in the early 1990s Gough et al. (1997) placed Finland, Denmark and Sweden in the "citizenship-based but residual assistance" category, whereas social assistance in Norway was categorised as "decentralized, discretionary relief". Norway would accordingly appear to have been somewhat less centralized than the other three. ${ }^{2}$

\subsection{Denmark}

Social assistance in Denmark was originally an entirely discretionary benefit that gradually has been turned into a standardised allowance (Heikkilä et al. 2001). This process started already in the 1970s when ceilings for social assistance were established and continued in 1987 when nationally fixed rates for the basic benefit were introduced.

The recession in the 1990s combined with perceived welfare state passivity triggered a series of activation reforms. Denmark's first mandatory activation program, the Youth Allowance Scheme for 18-19 year old recipients, was introduced in 1990. In 1991 municipalities received the right to act as an employment service for especially vulnerable individuals in all age groups. Activation efforts were then gradually expanded,

\footnotetext{
${ }^{2}$ This categorization contrasts with that of Hölsch and Kraus (2006) who classified the Swedish social assistance scheme as less centralized than Denmark and Finland (Norway was not included). A more recent typology placed social assistance in Finland, Norway, and Sweden in a group labelled local autonomy centrally framed (Denmark was not included) (Kazepov 2011). However, within this group the larger central control in Finland compared with the other two countries was emphasised (Minas and Øverbye 2010). The assessments of the extent of local discretion in other words differ. Still, one reason for the differences in the classifications may also be that they refer to different time periods, and as we shall see below level of decentralisation in the social assistance schemes is something of a moving target.
} 
in 1992 including unemployed under the age of 25 on social assistance benefits and in 1996 those under 30. The benefit was turned into taxable income (1994) and discretionary supplements almost entirely abolished (Heikkilä et al. 2001). The Law on Municipal Activation (1994) expanded the target-group for activation to also include social assistance recipients above 25 years and also persons considered to have other problems in addition to unemployment. However, in 1996 this municipal obligation changed to municipal discretion as local authorities now could decide to formulate action plans if deemed necessary in the individual case (Bredgaard 2001). With the Law on Active Social Policy (1998) the obligation to participate in activation programs was extended to social assistance claimants between ages 25 and 30 (Rosdahl and Weise 2000). Local authorities were required to offer activation programs but were allowed discretion regarding the form of activation. Moreover, while municipalities previously could sanction non-compliance with discretionary reductions of benefits within narrow bands, new acts $(1998,2000)$ standardised benefit reductions in such cases (Kvist and Meier Jæger 2004).

Subsequently, the reform "Bringing More People into Work" (2002/03) introduced a social assistance ceiling and reduced assistance in a number of situations to force people into employment. ${ }^{3}$ In addition, the law on immigration (2002) drastically limited immigrants' access to social assistance, introducing a seven-year qualifying period for full benefits during which immigrants could only receive a lower integration allowance (Goul Andersen 2007). In 2006 another programme, “A new chance for everyone”, primarily targeted at immigrants and their offspring who were not subject to the integration program, made cash assistance for people between 18 and 25 conditional on participation in education activities (Liebig 2007). Standardisation also increased as central rules and manuals were introduced to control local actors and measures encouraged/obliged municipalities to contribute more actively to the inclusion of unemployed (UWT 2007).

\footnotetext{
3 The reform also integrated the national PES and the municipal employment services, abolishing the distinction between municipal activities for social assistance recipients and the public employment service' activities for unemployment benefit recipients. This initiated a reform process resulting in the introduction of so-called job-centers in each municipality (Minas forthcoming), yet this occurred in 2007 and will therefore not be covered by our analyses.
} 
In sum, although the development after 1990 is characterised by increasing local responsibility for activating social assistance recipients this remains under central control. The latter is evident in a continuous standardisation of the benefit, obligations implying harder sanctions and lower benefit levels as well as extensions of the target group for activation. Organisationally there has been an attempt to establish closer links between social and labour market policy (integration).

\subsection{Finland}

A gradual standardisation of the benefit level has also occurred in Finland and municipal discretionary power has been successively reduced. A national monetary standard was for instance introduced in 1989. However, recent reforms contained elements of decentralisation. First out is the VALTAVA reform (1992) implying a shift of regulatory power from central and provincial government to municipalities which obtained the right to distribute government grants and also increased leeway in deciding how to organise services. The social assistance act (1998) gave social workers the power to reduce social assistance in case of refusal of work or training, although sanctions were regulated nationally. The Act on Rehabilitating Work Experience (2001) authorized municipalities to organize active labour market programs or purchase programs from non-state actors.

The 2001 act also promoted closer integration of activation measures carried out by local employment and social welfare offices. The key element in the reform was the activation plan which officers from the Public Employment Service (PES) and from the local authorities were obliged to prepare together with the unemployed social assistance recipients. Institutional integration of activation services was further enhanced in 2002 and 2003 when services provided by employment offices, municipalities, and the social insurance institution were brought together in so-called Joint Service Centres (JOIS) on experimental basis at local level. These were 2004 divided into joint municipal-state Labor Force Service Centres (LAFOS) for unemployed with multiple problems and Job Search Centres for job-ready unemployed. LAFOS were established after voluntary agreements at the local level and thus do not exist everywhere. They include public 
employment services, social and health care services, services of the national social insurance agency as well as other experts if needed (Minas forthcoming).

A mixed vertical shift occurred in 2006 when the financing responsibilities of central and local government were changed to increase the incentives for municipalities to organise activation programs for long-term unemployed. Municipalities now had to co-finance $50 \%$ of the benefit while the state covered costs for activation.

Summarizing these developments it is possible to talk about a tendency towards standardization of the benefit, but also increased local autonomy within the centralized framework and a strong trend towards an integration of various services directed at recipients with more serious problems far from the labour market.

\subsection{Norway}

Extensive local discretion is a main feature of the Norwegian social assistance scheme. No national monetary standard exist instead assessment of benefit levels is up to social workers at the municipal level. Since 1991, municipalities have the right to condition social assistance benefits on work or retraining activities, yet without specifications regarding target group, sectors in which work can take place, duration etc. (Lødemel and Trickey 2000). Municipalities have maintained their prerogatives regarding benefit rates after the introduction of governmental guidelines on social assistance (no legally binding standards) in 2001.

Large differences in municipal activation efforts created demands for better linkages between municipal social policies, health-related services and central government's labour market policies (Øverbye 2010). Increased emphasis on welfare-to-work policies and ambitions to modernize the welfare state resulted in the Action Plan to Combat Poverty in 2002. The plan contained a broad spectrum of rehabilitation and activation measures to be implemented over the following years targeted at young social assistance recipients (20-24), single parents, long-term recipients, immigrants and people who receive drug substitution treatment (Rønsen and Skarðhamar 2009). The Action Plan 
emphasized closer cooperation between the PES and social welfare system. Intensified cooperation was also a goal in the amendment to the Act on Social Services in 2004. Social assistance recipients were granted the right to an "individual plan" worked out between the social worker, the client and other relevant actors. A program for newly arrived immigrants lacking basic qualifications was introduced simultaneously entitling and obliging them to partake in individually planned training programs. This so-called introduction program was initially a voluntary program for the municipalities in 2003 becoming compulsory in 2004. Participants were entitled to an introductory benefit financed directly by the state, not by local councils. ${ }^{4}$

In summarizing the development in Norway, two features can be emphasized. First the high degree of local discretion and second the increasing efforts to integrate labour market and social welfare systems in recent years.

\subsection{Sweden}

Sweden did not see as many reforms as the other countries. From the beginning of the 1990s Swedish municipalities increasingly required participation in activation programs of social assistance recipients. This accelerated in 1994 when government declared that every unemployed under age 25 unable to find work within three months should be offered placement in labour market programs (Bergmark 2001). Responsibility for labour market measures for unemployed youths under age 20 was transferred to the municipalities (1995) and later expanded to young people between 20 and 24 (1998). The revision of the Social Service Act (1998) also gave municipalities the option of making participation in activation programs obligatory for social assistance recipients between 20 and 24 years of age and to refuse or lower benefits for individuals not participating in assigned programs. Thus, local autonomy increased. However the revision in addition introduced a national monetary standard aimed at reducing local variation in social assistance payments, implying a simultaneously reduction of local autonomy. The impact of this reform is nevertheless unclear as the standard only stipulated minimum amounts

\footnotetext{
${ }^{4}$ At this time the Norwegian parliament also started considering combining the social service, the labour market and the social insurance agencies which in 2006 resulted in the merger of the employment and national insurance services (Minas forthcoming). As in the Danish case this will not covered by these analyses.
} 
for certain core items, leaving it to municipalities to decide on additional items and greater amounts.

The development in Sweden can be summarized as a decentralisation trend in the 1990s with increasing conditionality for social assistance receipt among youth. After 1998 the picture is more mixed although there may be some centralization. In contrast to the other countries we see an increased central steering of activation policies through a concentration of responsibilities to the PES.

\subsection{Expectations regarding variation in social assistance payments}

What does this imply for local variation? Based on the reform patterns in the different countries we would expect the following.

Denmark: decreasing variation among young recipients in the 1990s and after 2002 also among recipients with an immigrant background.

Finland: increasing variation in the 1990s, while it is difficult to form an expectation regarding the development after 2001 as institutional cooperation builds upon voluntarism.

Norway: unchanged variation in the 1990s, decreasing variation towards the end of the period because of extensive coordination efforts and increasing activation demands towards young social assistance recipients, single parents, immigrants and long-term recipients.

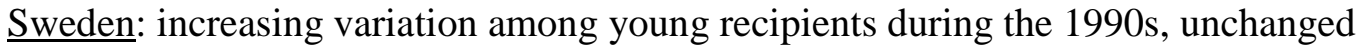
thereafter since national monetary standard implied decentralised centralisation.

\section{Data and method}

To isolate the effects of the legislative changes we need to eliminate other potential sources of variation such as individual differences or business cycle variations and for this purpose we employ multi-level modelling. In the case of individuals embedded, or 
clustered, in a geographical unit multi-level models decompose the total variance in the dependent variable into individual level (level 1) variance and variance at the geographical level (level 2). Formally the regression model we estimate can be expressed as:

$$
Y_{i j}=\beta_{0}+\boldsymbol{\beta}_{1} \mathbf{x}_{i j}+u_{0 j}+e_{0 i j}
$$

where $Y_{i j}$ is the annual social assistance benefits received by individual $i$ in municipality $j, \beta_{0}$ is the intercept, $\boldsymbol{\beta}_{1}$ is a vector of regression coefficients and $\mathbf{x}_{i j}$ represents its corresponding vector of covariates. Covariates can be measured on both levels.

However our main interest is not the effects of covariates, but the remaining random part of the equation where $u_{0 j}$ is the error term at level 2 and $e_{0 i j}$ is the error term at level 1. These capture variation in the dependent variable not captured by the rest of the model, and in this paper we focus on variance unexplained at the municipal level 2 . This consists of two components; one related to the composition of individuals within the $2^{\text {nd }}$ level and another 'real' contextual component that goes beyond the sheer composition effect. By including explanatory factors at both levels we reduce the impact of compositional effects on municipal variation and are therefore more likely to detect the impact of legislative change on the inter-municipal variance.

The parameters to be estimated in the random part of the model are the variances of the error terms, $\sigma_{u 0}^{2}$ and $\sigma_{e 0}^{2}$ respectively, indicating inter- and intra-municipal variation. We concentrate on changes in the unexplained variance at level 2 as a proportion of the total variation, the so-called variance partition coefficient (VPC). Then, the VPC $=\sigma_{u 0}^{2} /\left(\sigma_{u 0}^{2}+\right.$ $\left.\sigma_{e 0}^{2}\right)$. The evolution of the VPC in other words indicates changes in inter-municipal variation in social assistance payments not related to changes in covariates, which with an appropriate selection of covariates will indicate the effect of the legislative changes. This model has then been estimated separately for each country, year, and demographic group. 
The data that has been used consists of national register data for each country covering a time period from the beginning of the 1990s until late 2000s. More specifically, the Danish data span the period 1990 to 2007, the Finnish data the period 1993 to 2010, Norwegian data the period 1993 to 2007, and the Swedish data the period 1990 to 2007. In all four cases, the data consists of administrative data collected in connection with the payment of transfers and collection of taxes. The Finnish and Norwegian data covers all social assistance recipients, the Swedish a $50 \%$ random sample thereof while the Danish covers a $10 \%$ sample of the population born in Denmark as well as all immigrants. We examine recipients between ages 18 and 64 . The dependent variable refers to total annual individual social assistance payments, in Denmark kontanthjoelp, in Norway to sosialstøtte, in Finland toimeentulotuki and in Sweden socialbidrag. Social assistance has been measured in local currencies and inflation adjusted to 2006 prices.

The independent variables included in the analyses have been chosen to capture both individual and municipal level variation in the likelihood of social assistance receipt. The individual level variables that have been used are age, born abroad, recent immigration $(<=5 \mathrm{yrs}$.), educational level (5 levels), children under the age of 18 in the household, whether the individual lived alone, received any sick pay during the year, and been unemployed without receiving any form of unemployment compensation. The municipal level variables include population size, the proportion of the population of working age that were between the ages 18 to 19,20 to 24 , and 25 to 64 , the proportion of immigrants of the population, of sick pay recipients, and of unemployed without unemployment compensation, as well as the average employment earnings in the municipality. ${ }^{5}$ The variation in space and time in these variables is intended to capture differences in benefit receipt not related to the reforms.

The analyses have been conducted separately for the different groups that have been the target group for the various reforms, e.g. immigrants or 20- to 24-year olds. The

\footnotetext{
5 The Finnish data differs slightly as it lacks individual level information on birth place, immigration date, educational level, and sick pay receipt. In addition, unemployment here measured long-term unemployment ( $>=6 \mathrm{mo}$.), proportion immigrants the proportion with a foreign mother tongue, proportion unemployed the unemployment rate, and average employment earnings in the municipality the average municipal earnings in 2010.
} 
development of the VPC for these groups is then compared with the variation among 25to 64-year olds. This group, the 25- to 64-year old recipients, will generally act as "comparison group" as most reforms were directed at other groups of recipients. A reform is considered to have had an effect if there are changes in variation in the expected direction for the affected group without there being simultaneous similar changes for the comparison group of 25- to 64-year olds. An exception is of course reforms affecting all recipients, such as the Finnish reforms, for which we can only look at the overall development. The structure of the analyses is thus akin to a so-called difference-indifference model in which changes in the treatment group are compared to changes in a comparison group.

Nevertheless, the analysis of institutional reforms is often complex. Many reforms have been initiated in each country implying shifts of power in various directions. Some were enacted late in the period examined here and it may therefore be too early to identify their effects, some reforms were directly followed by others strengthening, counteracting or neutralizing the effects of the original reform. Implementation research has furthermore shown that reforms not necessarily develop as intended by legislators. Moreover, the political discussion prior to a reform may in itself change the behaviour of social welfare agencies and social workers, and in some cases new legislation may only turn already existing practices in law. Identifying a "reform effect" may therefore be quite difficult. For these reasons we will not take the date of legislation as the exact date of a reform but rather look at a "window" around the enactment date. Likewise, the focus will not necessarily be solely on individual reforms but also on packages of reforms that may increase or decrease local autonomy with respect to social assistance policies.

\section{Results}

The VPC from models with all covariates included are presented in graphs showing their evolution for each country and group. Vertical bars in the graphs indicate reform years. After the inclusion of the control variables, municipal variation in all countries lies roughly around 10 per cent of the total variation. Empty models without covariates are not show, but VPCs are in all cases around 5 percentage points higher in the empty models than in those presented. 


\subsection{Denmark}

Starting off with Denmark, as shown in Figure 1 inter-municipal variation among 25- to 64-year olds is roughly halved during the 1990s and remains at a lower level during most of the 2000s despite notable annual fluctuations. Falling VPCs are also evident among youths and immigrants. ${ }^{6}$ Among youths the change in inter-municipal variation roughly parallels that among 25- to 64-year olds, although it seems to reach its lowest level already 1997 whereas the comparison group bottoms out in 2000. The fall in the VPC is however particularly dramatic among immigrants. Inter-municipal differences in social assistance payments among immigrants were originally twice as large as among 25- to 64-year olds, yet by the end of the period they had fallen by two-thirds to about the same level. It is also obvious that the immigrant VPC displays greater fluctuations than the others, presumably related to the changing composition of the immigrant group. Although we distinguish between recent and earlier immigrants we do not for instance differentiate based on country of origin.

- Figure 1 about here -

This general reduction in the VPC does however not seem to be related to the reforms. Recall that, although many of the reforms contained elements of standardization, most of the early reforms $(1992,1996,1998)$ were directed at youths, and despite not being targeted the development of the VPC among the 25- to 64-year olds is largely similar. Likewise, immigrants became the target of reforms first after the turn of the millennium (2002, 2005), that is after their VPC had approached that of the other groups. It does however seem likely that the drop in the immigrant VPC after 2002 was at least partly caused by the reforms, recall that they included the introduction of a new standardized benefit that in many cases replaced discretionary social assistance. Apart from this it seems fairly clear that the changes in the VPC were not related to the reforms.

\subsection{Finland}

${ }^{6}$ Estimates for ages 20 to 24 are here missing for some years as the models did not converge. 
For Finland only one VPC curve is presented as reforms did not target any specific group of benefit recipients. Figure 2 shows that with regard to inter-municipal variation 2003 is a turning point. Specifically, there is a decade long slide in the VPC between 1993 and 2003, a slide followed by an almost uninterrupted rise between 2003 and 2010. The initial reduction is relatively small (about a third), and the same may be said of the subsequent increase.

- Figure 2 about here -

Regarding the reforms, the period of decline was actually a period of increasing local responsibility. The integration reforms in the latter half of the period were, in contrast, basically expected to produce a standardisation across municipalities and thus decreasing variation. However, as noted above the type of integration chosen in Finland has so far built upon local decisions regarding whether to introduce joint cooperation centres (in 2010 LAFOS existed in only around $40 \%$ of the municipalities) and regarding who is referred to LAFOS, and is furthermore characterized by weak national steering and aimed at a difficult target group (those "far from the labour market"). These are all aspects that might explain the slightly raising variation from 2003 onwards.

\subsection{Norway}

Turning then to Norway, as evident in Figure 3 there is very little fluctuation in the VPC in the comparison group of 25- to 64-year olds as well as among youths. Among single parents the VPC drops slightly during the 1990s only to trend upward after the turn of the millennium. The fluctuations are however fairly limited and the ups and downs furthermore basically cancel out leaving the VPC for this group at the end of the period at the same level as in the beginning. The greatest variation is instead, again, evident among immigrants were the VPC oscillates noticeably. An initial rise is thus reversed in 1995 with the reduction continuing until 1998. Another increase then ensues culminating in 2003 and in turn followed by a final drop.

- Figure 3 about here - 
That local variation for the most part would remain unchanged during the 1990s was expected. The only reform during this period, the sanctioning rights introduced in 1993, did not generate an increase in variation presumably due to the local reluctance in implementing the reform documented elsewhere (Lødemel 1997). The same applies to the guidelines introduced in 2001. Here we would expect a decreased VPC, yet no such tendencies are evident and the reason may again be an implementation deficit (Brandtzæg et al. 2006). The 2002 Action plan against poverty, the organizational reforms in 2004 and the introduction program were also expected to lead to a decreased VPC. There is actually a drop in the VPC among youths and single parents in 2005, yet this seems unlikely to be reform related as it is quickly reversed. The pronounced drop in the VPC for immigrants might be a result of the joint efforts towards activation, but even more likely is the launch of the introduction allowance. Although this benefit here is not counted as social assistance, in contrast to in our Danish analyses, its inception implies that many immigrant social assistance recipients were transferred to another scheme leaving a more homogenous recipient group with less variation.

\subsection{Sweden}

Finally the results for Sweden are shown in Figure 4. The VPC among adults displays an initial rise and subsequent stabilization, albeit with some short-term fluctuations. Among both youths and teenagers we see a somewhat similar pattern although with greater annual oscillations. It may be noted that Sweden is the only country where there has been an increase in variation, and that among all groups.

- Figure 4 about here -

Relating these developments to the various Swedish reforms suggest that they have had no effects. There is thus little indication that increased local responsibilities in 1995 affected local variation, the weak signs of rising VPCs occur prior to the reforms and is more clearly evident among groups not targeted. Nor do the reforms in 1998 affecting youths seem to have an effect. The effects of the other reforms introduced in 1998 also appear rather limited, if anything it seems as if the sanctioning rights and the right to 
decide on social assistance items have more than countered the introduction of the national norm as there are signs of a rising VPC in the comparison group.

\section{Discussion}

Variation in social assistance payments is an important issue within the perspective of social rights as the benefit functions as the last resort. Social rights legitimate claims that people as citizens make on benefits and social services from the state, guaranteeing a minimum of economic welfare and the possibility to participate in society according to the standards prevailing in the society (Rees 1996). In the social rights discussion the social insurance system has often been defined as central for realizing social citizenship, yet as emphasized by Marshall (1950) the provision of a certain minimum income for all members of society defines the very nature of social citizenship.

In all Nordic countries social assistance is an important component of the individual countries social security system. It stands only for a small proportion of all social expenditures, and the importance of social assistance varies over time but nevertheless it is crucial for a significant number of citizens. Reforms to these systems can serve multiple purposes, and have multiple effects. As reviewed above the last two decades have seen a number of reforms affecting the extent to which local governments (in the Nordic case municipalities) can influence the organization of and benefits paid through the national social assistance systems. The reforms have involved both increasing and decreasing local discretion, and sometimes a simultaneous mixture of the two. Increases in local responsibilities have generally been driven by a desire to provide municipalities an opportunity to adapt the programs to local conditions and priorities, and thereby potentially a better functioning system. Restrictions have on the other hand been generated by concerns regarding excessive variation in the municipalities' treatment of the benefit recipients.

The reforms in Denmark, Finland, Norway, and Sweden over the past two decades have clearly impacted on the administrative distribution of power. The theoretical as well as the empirical literature suggest that we may see an impact on the number of benefit claimants, benefit levels - and on benefit inequality. Generally speaking, decentralization 
was expected to increase variation in benefit payments across jurisdictions, and vice versa for centralization. In our investigation of these issues we attempted to improve on the methodological analysis of organizational reforms, developing an approach similar to the difference-in-difference methods applied in the treatment literature and using multivariate analysis.

The results can be loosely grouped into three categories; instances suggesting an impact of the reforms, instances where the lack of an expected effect can be explained by either the character or implementation of the reforms, and finally instances where an expected effect is missing yet no plausible explanation is available.

In the first category we find the two standardizations of benefits available for immigrants in Denmark and Norway. Not surprisingly, partial replacement of discretionary social assistance with a centrally determined introduction benefit appears to have decreased variation, either by standardizing the benefit itself (Denmark) or by homogenizing the recipient group (Norway). In the second group we find the decentralization of sanctioning rights in Norway, the standardizations of benefits through the introduction of national guidelines in Norway and Sweden as well as the institutional integration in Finland. The Norwegian reforms both seem to have been undermined by the implementation process in which caseworkers acted contrary to intentions. The Swedish and Finnish reforms instead appear to fall short because of the way the reforms where designed. Despite the guidelines, Swedish municipalities retained substantial discretion over the benefits thereby negating the attempt at standardization. (The Norwegian and Swedish guidelines also illustrate that not all reforms directly related to benefit structure need affect benefit inequality.) The Finnish service centres were voluntary and allowed substantial leeway in other respects as well. In these cases, the absence of the predicted effect does not appear surprising.

The final category is made up of reforms where no explanation for the absence of expected effects was readily apparent. This group is for obvious reasons difficult to interpret. However, it is notable that it mainly consists of the different activation reforms 
in the four countries, often directed at specific groups such as youth. The decentralization involved in these cases may for different reasons have been more apparent than real. Although these are only conjectures, it may for instance be the case that municipalities failed to make use of opportunities given to them, or that they introduced different activation measures yet without changing the benefit. Many of these reforms were also enacted during recessions, and another possibility is that sanctions against groups initially far from the labour market may then appear unreasonable. While no definite explanation for the lack of the expected effect can be provided here it seems as if activation reforms differ from the rest.

At a more general level reform effects appear to depend on the often complex nature of the reforms as well as the reform process itself and the context they are embedded in. With regard to the former, a specific reform may be difficult to characterize as a de- or recentralizing reform, instead reforms often contain aspects of both de- and recentralization. Although the national standard in Sweden aimed to reduce local autonomy and variation the remaining municipal discretion still counteracted the reform. Governance reforms such as integrated services that bridge several policy domains located at different territorial levels display an especially complex interplay between responsibility for service regulation, administration, delivery and financing.

Moreover, the reform process is not static and decentralizing reforms may be followed by centralizing ones and vice versa. As a particular reform may be implemented with some delay a series of reforms and counter-reforms may leave only limited imprint. As discussed above implementation may also deviate from the intended.

When it comes to the context, the political and administrative settings have to be taken into account. In general, the Nordic countries present similar contexts (unitary states, strong municipalities, framework legislation) even if they differ regarding local autonomy. However, decentralisation in highly decentralized countries (e.g. Italy) may differ from reforms in more centralized countries (e.g. France). Thus, similar reforms (e.g. the recent integrated services) are carried out in clearly different manners and 
contexts potentially effecting standardisation and local variation. Reforms in neighbouring policy areas (mainly labour market policy and education) may also impact on attitudes and/or local policies spilling over to social assistance payments.

Finally, this study has examined the link between the Nordic reforms and benefit inequality, and not assessed the appropriateness of variation in social assistance payments. However, the results indicate that to the extent that inter-municipal benefit variation is deemed problematic reducing benefit inequality may be difficult. Variation is fairly limited, even in the models without controls for individual and structural differences inter-municipal variation only accounts for around $15 \%$ of total variation. Introducing controls diminishes variation even further, suggesting that the possibility for reforms to affect benefit inequality is small. This may of course be due to the fact that this is a discretionary benefit, and short of replacing it with standardized benefits reforms may be ineffectual. On the other hand, the fact that variation appears relatively limited suggests that the problem may be smaller than sometimes believed. 


\section{References}

Bergmark, A. (2001) 'Den lokala välfärdsstaten? Decentraliseringstrender under 1990talet'. In Szebehely, M. (ed.) Välfärdstjänster i omvandling, SOU 2001:52, Stockholm: Fritzes.

Bergmark, A. and Minas, R. (2007) 'Decentraliserad välfärd eller medborgerliga rättigheter? Om omfördelning av makt och ansvar mellan stat och kommun', Socialvetenskaplig tidskrift, no 2-3, pp 220-241.

Blank, R. M. (2002) 'Evaluating Welfare Reform in the United States', Journal of Economic Literature, vol 40, pp $1105-1166$.

Brandtzæg, B., Flermoen, S., Lunder, T. E., Løyland, K., Møller, G. and Sannes, J. (2006) Fastsetting av satser, utmåling av фkonomisk sosialhjelp og vilkårsbruk $i$ sosialtjensten. Rapport nr. 232. Telemarksforsking-B $\emptyset$.

Bredgaard, T. (2001) 'A Danish Jobtraining Miracle? Temporary subsidised employment in the public and non-profit sector', Working paper no 5, Centre for Labour Market Research, Aalborg University.

De Vrijes, M. (2000) 'The rise and fall of decentralization: A comparative analysis of arguments and practices in European countries', European Journal of Political Research, vol 38, pp 193-224.

Esping-Andersen, G. (1990) Three world of welfare capitalism. Oxford: Oxford University Press

Gough, I., Bradshaw, J., Ditch, J., Eardley, T., and Whiteford, P. (1997) 'Social Assistance in OECD Countries', Journal of European Social Policy, vol 7, no 1, pp 1743.

Goul Andersen, J. (2007) 'Restricting access to social protection for immigrants in the Danish welfare state', Benefits, vol 15, no 3, pp 257-269.

Heikkilä, M., Fridberg, T. and Keskitalo, E. (2001) 'Guaranteed Minimum Income Recent trends and a Socio- Political Discussion', in Heikkilä, M. and Keskitalo, E. (eds), Social Assistance in Europe, Helsinki: STAKES/EU.

Hölsch, K. and Kraus, M. (2004) 'Poverty Alleviation and the Degree of Centralization in European Schemes of Social Assistance'. Journal of European Social Policy, vol 14, no 2, pp 143-164.

Hölsch, K. and Kraus, M. (2006) 'European schemes of social assistance: an empirical analysis of set-ups and distributive impacts', International Journal of Social Welfare, vol 15, iss 1, pp 50-62.

Johansson, H. (2001) I det sociala medborgarskapets skugga - rätten till socialbidrag under 1980- och 1990-talen. Lund: Arkiv.

Kazepov, Y. (ed) (2011) Rescaling social policies towards multilevel governance in Europe, Fernham: Ashgate.

Kneebone, R. D., and White, K. G. (2009) 'Fiscal Retrenchment and Social Assistance in Canada', Canadian Public Policy/Analyse de Politiques, vol 35, no 1, pp 21-40. 
Kvist, J. and Meier Jæger, M. (2004) 'Changing the social rights and obligations of social citizenship in Europe. The case of in unemployment compensation, social assistance and family benefits in the 1990s', Danish National Institute of Social Research, Copenhagen, downloaded http://www.issa.int/pdf/initiative/reports/2Denmark.pdf.

Liebig, T. (2007) 'The Labour Market Integration of Immigrants in Denmark', OECD Social, Employment and Migration Working Papers no 50, DELSA/ELSA/WD/SEM(2007)5, OECD, Paris.

Lødemel, I. (1997) The welfare paradox: income maintenance and personal social services in Norway and Britain, 1946-1966, Oslo \& Stockholm: Scandinavian Univ. Press.

Lødemel, I. and Trickey, H. (2000) An Offer you Can't Refuse. Workfare in international perspective, Bristol: Policy Press.

Marks, G., Hooghe, L. and Schakel, A.H. (2008) 'Measuring Regional Authority', Regional and Federal Studies, vol 18, pp 111-121.

Marshall, T. (1981) The right to welfare and other essays. London: Heinemann.

Martínez-Vázquez, J. and McNab, R. (2003) 'Fiscal Decentralization and Economic Growth', World Development, vol 31, iss 9, pp 1597-1616.

Meyers, M. K. and Gornick, J. C. (2005) 'A devolution revolution? Change and continuity in U.S. state social policies in the 1990s', in Cantillon, B. and Marx, I., International cooperation in social security: How to cope with globalization?, Amsterdam: Intersia.

Meyers, M. K., Gornick, J. C., and Peck, L. R. (2002) 'More, Less, or More of the Same? Trends in State Social Welfare Policy in the 1990s', Publius: The Journal of Federalism, vol 32, no 4, pp 91-108.

Minas, R. (forthcoming) 'One-stop shops: Increasing employability and overcoming welfare state fragmentation?', International Journal of Social Welfare.

Minas, R. and Øverbye, E. (2010) 'The territorial organization of European social assistance schemes', in Kazepov, Y. (ed.) Rescaling of Social Welfare Policies. A comparative study on the path towards multi-level governance in Europe. London: Ashgate.

Minas, R., Wright, S. and van Berkel, R. (2012) 'Decentralization and centralization: governing the activation of social assistance recipients in Europe', International Journal of Sociology and Social Policy, vol 32, no 5, pp 286-298.

Mosley, H. (2003) 'Flexibility and Accountability in Labour Market Policy: A Synthesis', in OECD Managing Decentralisation. A New Role for Labour Market Policy, Paris: OECD Publishing.

Mosley, H. (2009) 'Decentralization and Local Flexibility in Employment Services', in Larsen, F. and van Berkel R. (eds.), The New Governance and Implementation of Labour Market Policies, Djoef Publishing.

Oates, W. (1972) Fiscal Federalism. New York: Harcourt, Brace, Jovanovich.

Osborne, D. and Gaebler, T. (1992) Reinventing Government: How the Entrepreneurial Spirit is Transforming the Public Sector, Reading, MA: Addison-Wesley. 
Pollitt, C. (2005) 'Decentralization: a central concept in contemporary public management', in Ferlie, E., Lynn, L. and Pollitt, C. (Eds), The Oxford Handbook of Public Management, Oxford University Press, Oxford.

Prud'homme, R. (1995) 'The dangers of decentralization'. World Bank Research Observer, vol 10, no 2, pp 201-220.

Rees, A. M. (1996) 'TH Marshall and the progress of citizenship', in Bulmer, M. and Rees, A. M. (eds), Citizenship Today, London: UCL Press.

Rodden, J. (2004) 'Comparative federalism and decentralization: On meaning and measurement', Comparative Politics, vol 36, pp 481-500.

Rodriguez-Pose, A. and Ezcurra, R. (2010) 'Does decentralization matter for regional disparities? A cross-country analysis'. Journal of Economic Geography, vol 10, pp 619-644.

Rosdahl, A. and Weise, H. (2000) 'When all must be active - workfare in Denmark', in Lødemel, I. and Trickey, H. (eds.), An Offer you Can't Refuse. Workfare in international perspective, Bristol: Policy Press.

Rønsen, M. and Skarðhamar, T. (2009) 'Do welfare-to-work initiatives work? Evidence from an activation programme targeted at social assistance recipients in Norway', Journal of European Social Policy, vol 19, no 1, pp 61-77.

Stranz, H. (2007) 'Utrymme för variation. Om prövning av socialbidrag', Institutionen för socialt arbete - Socialhögskolan, Stockholm Universitet.

Terum, L. I. (2003) Portvakt $i$ velferdsstaten. Om skjønn og beslutninger $i$ sosialt arbeid, Oslo: Kommuneforlaget.

Tselios, V., Rodríguez-Pose, A., Pike, A., Tomaney, J. and Torrisi, G. (2012) 'Income inequality, decentralisation and regional development in Western Europe'. Environment and Planning A, vol 44, no 6 pp 1278-1301.

UWT (2007) 'Denmark Country Report', Roskilde University, downloaded from http://www.undocumentedmigrants.eu/library/s15990_3.pdf.

Van Berkel, R., de Graaf, W. and Sirovátka, T. (2011) The Governance of Active Welfare States in Europe, Basingstoke: Palgrave Macmillan.

Van Mechelen, N. and De Maesschalck, V. (2009) 'Devolution of social security arrangements', in Cerami, A. and Vanhuysse, P. (eds) Post-Communist Welfare Pathways. Theorising Social Policy Transformations in Central and Eastern Europe, Basingstoke: Palgrave Macmillan.

van Oorschoot, Wim (no date) 'Comparative welfare state analysis with survey-based benefit recipiency data. The 'dependent variable problem' revisited introducing a new perspective on welfare state clustering', Paper presented at the Swedish Institute for Social Research, Nov. 14, 2012.

Øverbye, E. (2010) Activation and the coordination problem. Socialpolitik i förändring utveckling mot flernivåstyrning i Europa. Oslo: Högskolen i Oslo og Akershus. 


\section{Figures}

Figure 1. Inter-municipal variation in social assistance payments in Denmark. Variance partition coefficient from multi-level analyses, by recipient group and year

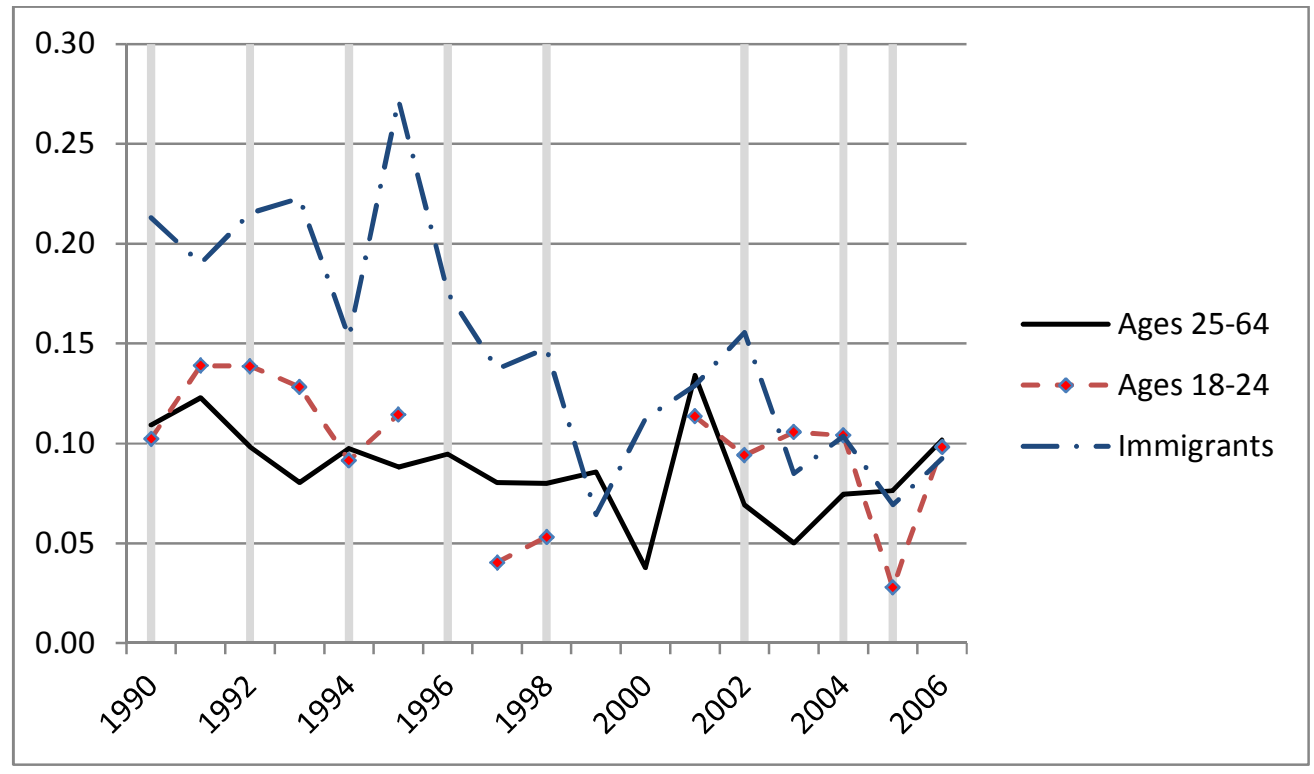

Figure 2. Inter-municipal variation in social assistance payments in Finland. Variance partition coefficient from multi-level analyses, by recipient group and year

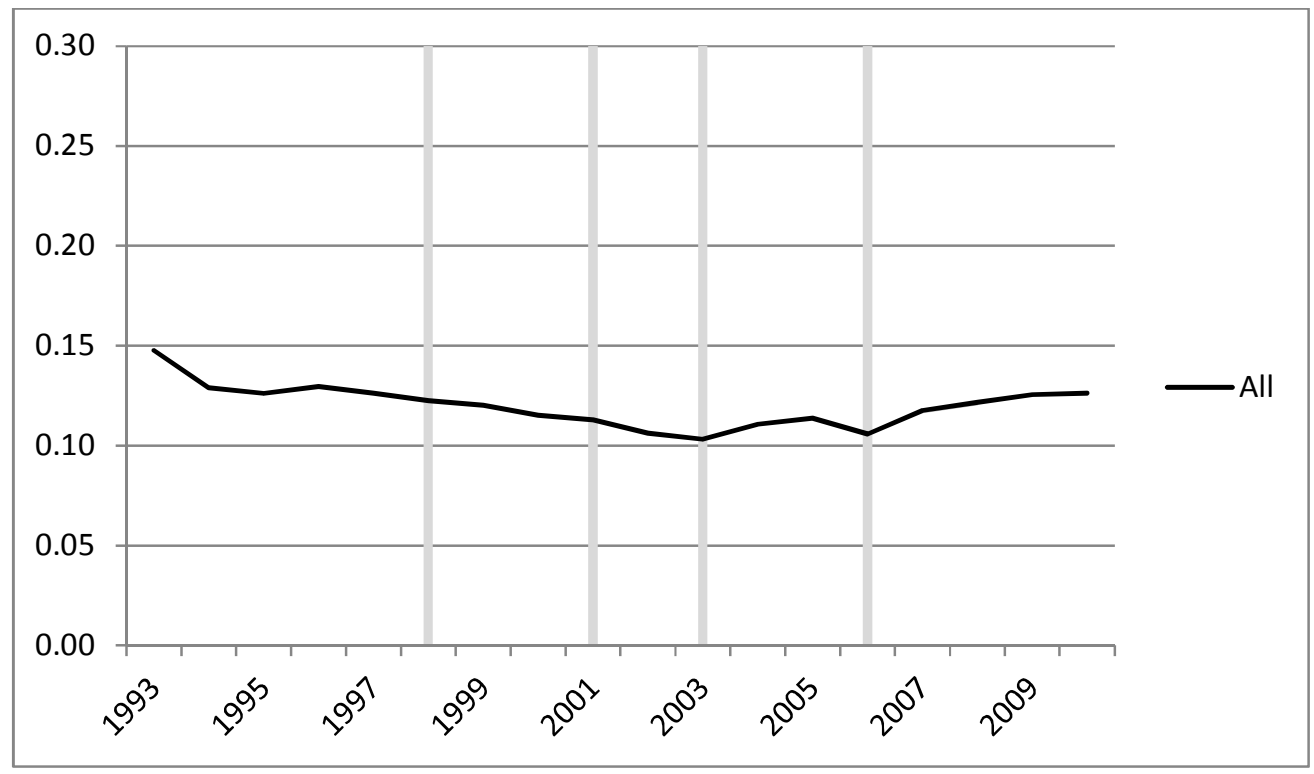


Figure 3. Inter-municipal variation in social assistance payments in Norway. Variance partition coefficient from multi-level analyses, by recipient group and year

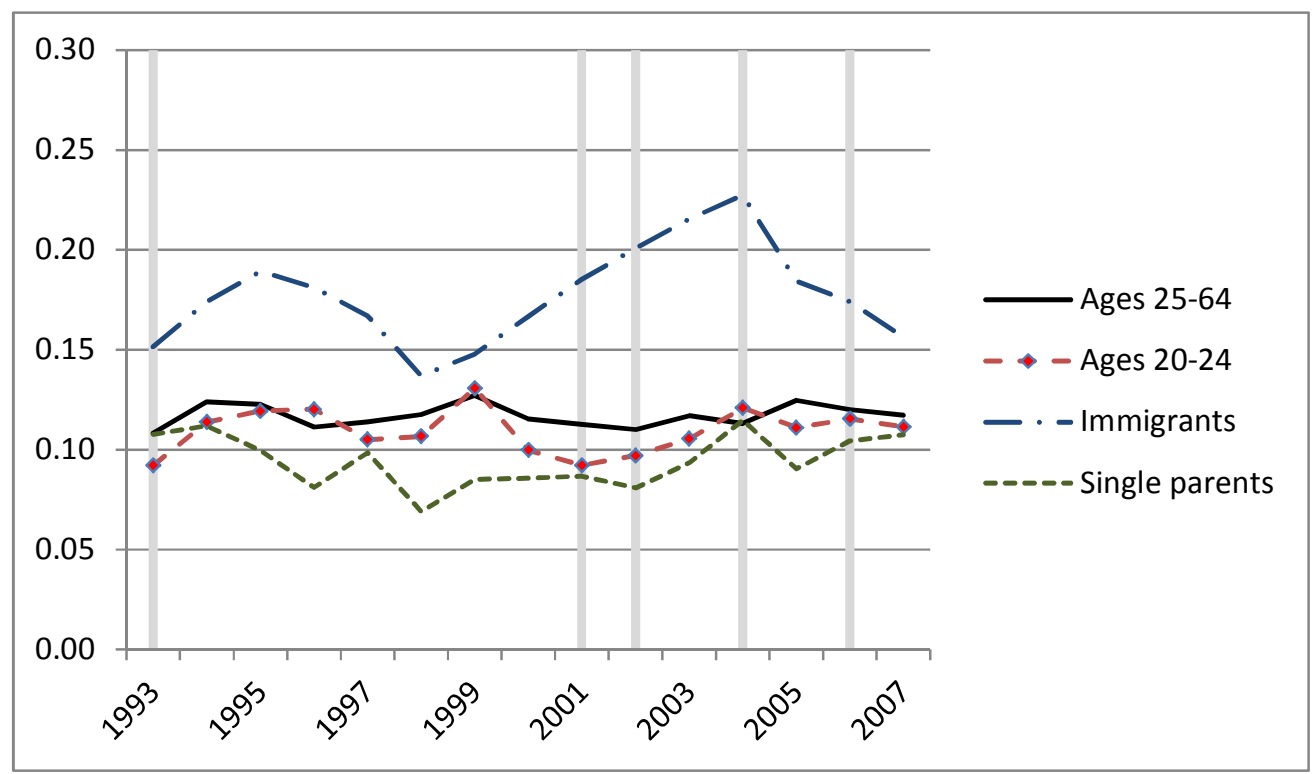

Figure 4. Inter-municipal variation in social assistance payments in Sweden. Variance partition coefficient from multi-level analyses, by recipient group and year

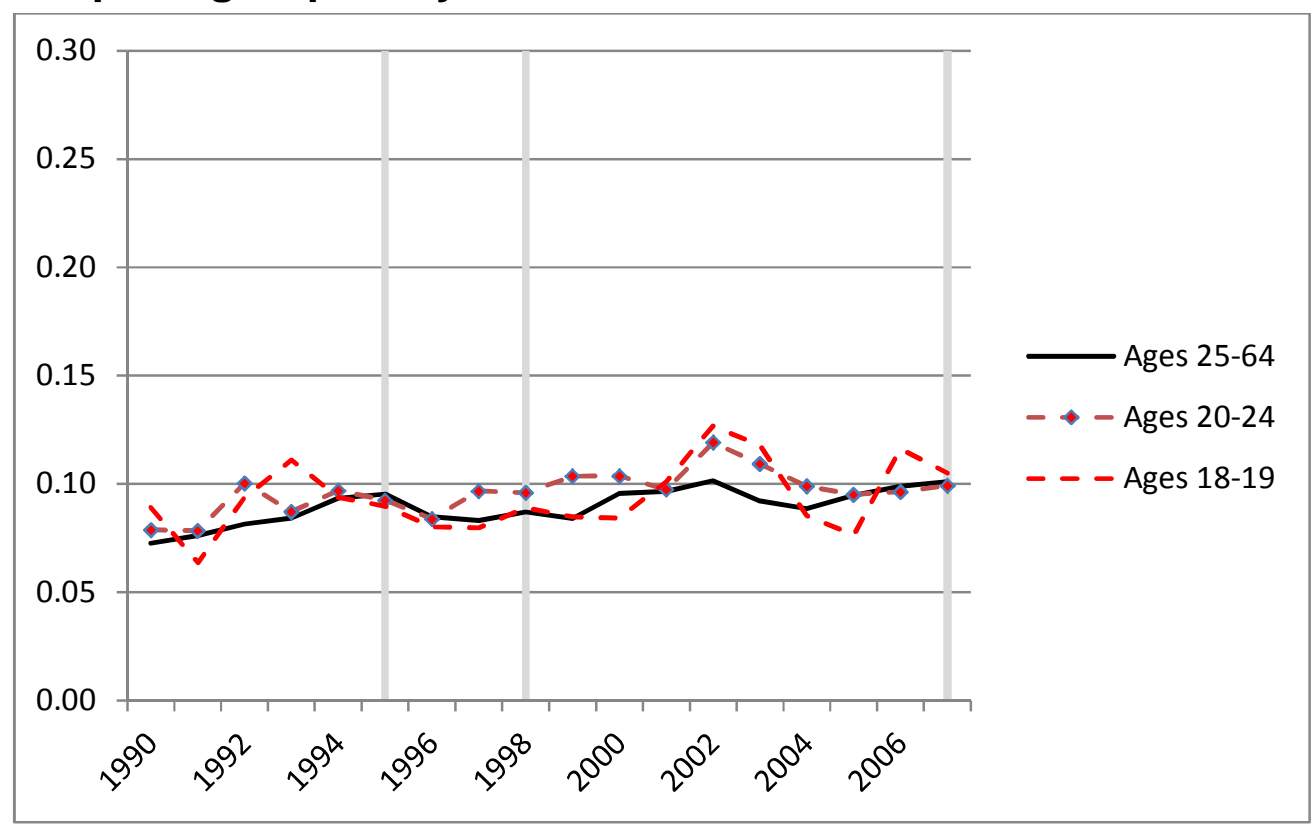

